DE DE GRUYTER OPEN
Journal of Intercultural Management

Vol. 6, No. 4, part II, December 2014, pp. 75-85

DOI 10.2478/joim-2014-0058

Krystyna Leszczewska ${ }^{1}$

College of Computer Science and Business Administration in Łomża

\title{
The Functioning of Small and Medium-Sized Enterprises in Conditions of Economic Stability
}

\begin{abstract}
Modern companies operate in an unstable environment. This requires management of the companies to undertake adjusting measures that will enable companies to survive and achieve competitive advantage. Increasing the risk of doing business has prompted the author to undertake empirical studies of the SME sector and to identify the types of risks faced by entrepreneurs. The article presents the results of empirical studies and contains conclusions that may serve as an advice for the SME sector.
\end{abstract}

Keywords: economic instability, SME sector

\section{Introduction}

Enterprises that want to survive and achieve a competitive advantage should have the ability to adapt to the market situation. Environment in which they operate today A. Koźmiński defines as a "generalized insecurity" [Kozminski A.K., 2004, p. 27]. Entrepreneurs for many years were accustomed to the evolutionary changes. This led to the activity model maladjusted to today's era of strong fluctuations. The unpredictability of changes faced by enterprises today makes their response to market situations sometimes delayed. Therefore, there may appear asymmetric responses - the market flexibly adapts to changes, whereas companies respond with a delay, inappropriately to the scale of changes [R. Foster, S. Kaplan, 2003, p. 33]. P. Kotler, J.U. Caslione believe that the new normality of economy is the fluctuations and shocks that increase the risks and uncertainty of conducting business activity on the macro and micro level [Kotler P., Caslione J.U., 2009, p. 32].

1 k.leszczewska@wp.pl 
Companies operating under turbulent environment must perform continuous analysis of sensitivity, that is, analysis of changes of conditions and information, which were the basis of the decisions made earlier [Szymański W., 2012, p. 22]. Changes may become an inspiration to create new innovative solutions, be an impulse to restructure the company, but they can also cause the collapse of the company, when the managers do not react quickly enough, do not take activities that enable survival in a turbulent environment. The increasing risk of doing business resulting from the instability of the environment in which contemporary enterprises operate prompted the author to undertake empirical research of the SME sector and to specify the types of risks faced by entrepreneurs ${ }^{2}$. The purpose of this article is to discuss the functioning of the SME sector in terms of economic instability. Analysis was based on empirical research, literature and observations and reflections of the author.

\section{The impact of economic instability on behaviour of enterprises}

The speed and unpredictability of changes in the environment requires from enterprises other strategies than those that have been effective in a period of stable conditions. Turbulent changes cause rapid aging of the products, information, acquired experience, strategy. Nowadays more and more visible, as defined by J.A. Schumpeter [Schumpeter J.A., 1992, p. 139], are the processes of creative destruction - an enterprise when adapting to the uncertainty and unpredictability rejects the old methods and replace them with new ones. Economic instability faced by enterprises can be described in three areas: market volatility, financial instability, instability in the business environment. Depending on the severity of these phenomena, there may occur a decline in economic activity, the reduction of incomes of enterprises and population.

Market instability manifests itself in many ways. High sensitivity of enterprises to changes in the volume of demand for goods and services compels them to actions aimed at stiffening the demand for manufactured products. Procedure that allows for the reduction of risk associated with the uncertainty of the market is an active influence on the patterns and structure of consumption by shaping the needs of buyers. Motives of consumers today are not always based on rational or economic calculation, these criteria are replaced by imitation, fashion, impulses inherent in the sphere of man's subconscious [Pietrewicz J.W., 2012, pp. 36 -37]. The speed at which enterprises adapt to the new structure of demand resulting from the new market conditions depends on the mobility of production factors and profitability

\footnotetext{
2 Research results presented in the paper are a part of the work performed by the author within the statutory study of the Collegium of Business Administration of the Warsaw School of Economics in 2013 titled "The impact of economic instability on the functioning of the SME sector in Poland" in a team led by prof. dr hab. R. Sobiecki.
} 
of production. The predicted high adjustment costs and risks connected with them, stiffen behaviour of enterprises towards ongoing changes.

Free operation of the market mechanism in the conditions of economic globalization causes the disappearance of barriers that restrict competition and protect the economically weaker countries and companies operating in their area against external competitors. This forces enterprises to change their attitude towards competition. Awareness of such risks makes the enterprises, regardless of the scale of business, to take into account market signals on the intensity of competition and adjust undertaken competition strategies to these realities. The processes of economic globalization lead to reduction of the possibility of state influence on economic processes. A role of macroeconomic interests is weakened in favour of microeconomic interests. Such a change in the balance of power in the economy limits the state's capacity to react in order to absorb the negative effects of externalities caused by the market mechanism.

\section{Change of the business model as a way to respond to the instability of the environment}

Dynamic changes in the business environment have effects for control of the enterprise both in terms of strategic and operational management. In the literature there are views that under such conditions the traditional approach to the management is not very useful. New conditions for enterprises, new market opportunities are the basis for creating new ways of creating value, new ways of organizing activities and use these changes as an opportunity for the company [Davenport T.H., Leibold M., Voelpel S., 2006, p. 25]. The increase of the complexity of the environment, the increase of uncertainty and risk requires the use of another method of enterprise management taking into account these variables. In this situation, in the early twenty-first century in the strategic management the dominant approach becomes the business model [Duczkowska-Malysz K., Duczkowska-Piasecka M., 2012, p. 149].

The speed of changes in the market makes even the most relevant elements of the business model and the pattern of their relationships unstable. Managers have to change some elements of the model in order to stay ahead of their competitors in this way. In many sectors, the operating conditions are changing so fast that companies must re-define their business models [Brzóska J. 2009, p. 13]. It happens that a company meeting the needs of several segments of customers, applies to each of them a different business model. It is usually justified by the desire to oust competitors or outperform them on existing markets, the intention to enter new markets, the drive for more efficient resource management and generation of new revenue streams [Casadeus-Masanell R., Tarzijan J., 2012, p. 95]. The consequences of the changes occurring in the business environment manifest themselves in business models, and as a result are reflected in the profitability of enterprises. 
Continuous redefining of the business model seems to be in the conditions of turbulent changes in the economic environment a necessary action to anticipate the behaviour of competitors. Competitors are able to force the company to lower prices of products, to provide customers with the offer of greater value. The rivalry also includes competition for resources: raw materials, commodities, talented employees. Factors forcing changes in business models of contemporary businesses are largely dynamic changes in technology, which provides the basis for the production of goods and services.

To determine whether the business model implemented so far in the enterprise is adequate for the conditions in which the enterprise operates, it is needed to analyze the hitherto effectiveness of the enterprises, the factors that determine its current level, as well as the processes of changes that may affect the future efficiency of the company. For this purpose it is necessary to analyze the competitive and macroeconomic environment of the company, indicate the strengths and weaknesses of the company, the foreseeable risks and opportunities for development. Analysis of the effectiveness of the company's activities should include the following: company's profitability, profit margin, cash flow, market share, market valuation of the company.

\section{Characteristics of the author's own research}

Empirical research conducted by the author among 58 enterprises of the SME sector in 2013 were aimed at examining, on the basis of the opinions of entrepreneurs, the types of risks faced by entrepreneurs and determining the effects of economic instability for conducting business. Companies participating in the study are located in the following voivodeships: podlaskie, mazowieckie, warmińsko-mazurskie, wielkopolskie i kujawsko-pomorskie. The samples for research were chosen purposeful, entities participating in the study varied in terms of size, organizational and legal form, place of business and business profile. Most strongly represented in the study were entities from the services and trade sector, which reflects the structure of the SME sector in Poland. The respondents were owners or managers of companies. Due to the researched issue, the companies that operate on the market relatively long were invited to participate in a pilot study.

Organizational and legal form of companies surveyed exposes typical for small and medium businesses dominance of entities run in the form of individual business activity (27 enterprises). Frequently represented in the sample were limited liability companies (13 enterprises) and the civil law partnerships (11 enterprises). Among surveyed enterprises were 3 general partnerships and 2 joint-stock companies, one limited partnership and one state-owned enterprise. From the perspective of the volume of employment, the sample was dominated by micro and small enterprises, which accounted for a total of $85 \%$ of the entities. $15 \%$ of surveyed enterprises 
belong to the group of medium-sized enterprises. Entities not employing workers did not participate in the sample, therefore the share of micro-enterprises in the surveyed group was lower than in the population of all enterprises. The examined enterprises were located in small towns (village - 10 enterprises in the group, towns with less than 20 thousand inhabitants -7 ), medium-sized towns (towns with population of 20-50 thousand inhabitants -5 enterprises, towns of 50-100 thousand inhabitants -28 ) and the cities of over 100,000 inhabitants -8 entities.

1. To verify the hypothesis assuming that small and medium-sized enterprises are feeling the increasing instability of external business environment the entrepreneurs were asked the following questions: Does the enterprise feel the risks in doing business associated with changes in market conditions?

2. Does the enterprise feel the financial risk in doing business?

3. What factors impede doing business in Poland the most?

\section{Risk in the SME sector in the light of the research}

Analysis of the market risk of the surveyed companies on the basis of the obtained answers can formulate an opinion that the greatest threat for economic activity are changes in the demand on the domestic market (this answer was given by $57 \%$ of respondents). The instability of demand is induced primarily by the decline of real income of the population and the inflow of substitute products from abroad. Other significant factors of market risk pointed by the respondents were domestic competition from large companies (50\% of responses), changes in the prices of raw materials (40\% of responses) and unfair competition (38\% of responses). Less importance the participants of the study attributed to changes of consumer trends, domestic competition from small businesses and companies operating in the shadow economy, competition from foreign companies (respectively 19\%, 17\%, $16 \%, 16 \%$ of responses). As the insignificant factors of uncertainty respondents recognized changes in demand on foreign markets, the risk of losing customers due to the lack of ability to build relationships with customers and cultural changes (respectively $7 \%, 2 \%, 2 \%$ of responses).

Analysis of financial factors relevant to doing business allows to conclude that the biggest hurdle for entrepreneurs are changing condition of the loans ( $43 \%$ of responses), changes in the conditions of using EU funds (38\% of responses) and changes in exchange rates (33\% of responses). As a particularly troublesome, respondents consider complicated banking procedures and conditions of the security of loans, which are difficult to meet, and complicated procedures of applying for EU funds. As the most important financial factor facilitating conducting business activity participants of the study recognized the reductions of interest rates $(14 \%$ of responses). 
Figure 1 Does the enterprise feel the risks in doing business associated with changes in market conditions? *

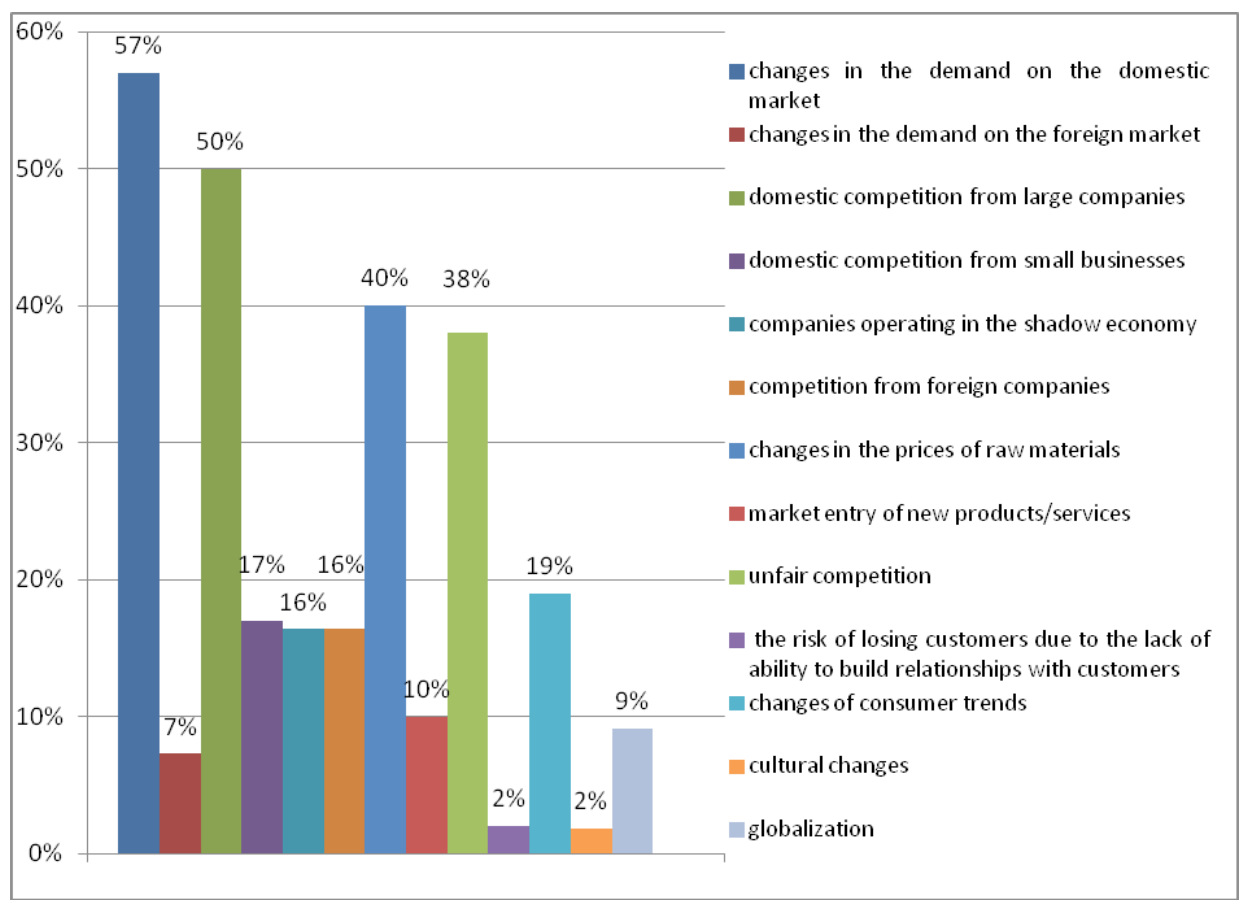

Source: Prepared on the basis of own research.

* respondents indicated 3 greatest risks in their companies

Table 1 How do the factors listed below affect the functioning of the enterprise?

\begin{tabular}{|c|c|c|c|c|}
\hline Specification & Hinder & No influence & Facilitate & $\begin{array}{c}\text { Not } \\
\text { applicable }\end{array}$ \\
\hline Changes of the interest rates & $29 \%$ & $24 \%$ & $14 \%$ & $33 \%$ \\
\hline Changes of the exchange rates & $33 \%$ & $26 \%$ & $2 \%$ & $40 \%$ \\
\hline Changes of the conditions of loans & $43 \%$ & $19 \%$ & $5 \%$ & $33 \%$ \\
\hline $\begin{array}{c}\text { Changes of the conditions of capital } \\
\text { investment }\end{array}$ & $14 \%$ & $19 \%$ & $9 \%$ & $59 \%$ \\
\hline Changes of the conditions of leasing & $12 \%$ & $14 \%$ & $9 \%$ & $66 \%$ \\
\hline Changes of the inflation rate & $31 \%$ & $22 \%$ & $7 \%$ & $40 \%$ \\
\hline $\begin{array}{c}\text { Changes of the conditions of the use } \\
\text { of EU funds }\end{array}$ & $38 \%$ & $7 \%$ & $10 \%$ & $45 \%$ \\
\hline
\end{tabular}

Source: Prepared on the basis of own research. 
Entrepreneurs asked, which factors impede conducting business activity in Poland the most could indicate the 3 major risks and difficulties that affect their business. The factor most hindering conducting business activity in the opinion of the respondents are highly burdened labour costs with social security contributions (64\% of responses). A large group of respondents said that significant obstacles in doing business are the changing, unclear tax law and high costs of tax settlements (respectively $52 \%$ and $45 \%$ of responses). The following factors limiting entrepreneurship in the opinion of the respondents are: long-lasting administrative procedures (29\% of responses), changing, overly complex reporting obligations (22\% of responses), and complex rules of public procurement (21\% response rate). The obtained results are closely related to the result of the research by the Ministry of Economy, the Confederation Lewiatan, Polish Agency for Enterprise Development and the author's own research conducted among the SMEs operating in the Podlaskie [Przedsiebiorczosś .., 2013 Black list of barriers .., 2013 .. Global Report, 2012].

Table 2 Factors hindering conducting business activity in Poland the most*

\begin{tabular}{|c|c|}
\hline Specification & Response rate \\
\hline Political instability & $10 \%$ \\
\hline Changing, unclear tax law & $52 \%$ \\
\hline High costs of tax settlements & $45 \%$ \\
\hline Companies registration costs & $3 \%$ \\
\hline Bankruptcy costs & $2 \%$ \\
\hline Changes in the level of the minimum wage & $10 \%$ \\
\hline Changes in the conditions of hiring and firing workers & $17 \%$ \\
\hline Costs and complexity of employment documentation & $17 \%$ \\
\hline Long-lasting administrative procedures & $29 \%$ \\
\hline Highly burdened labour costs with social security contributions & $64 \%$ \\
\hline Changing, overly complex reporting obligations & $22 \%$ \\
\hline Complex rules of public procurement & $21 \%$ \\
\hline Other & $3 \%$ \\
\hline
\end{tabular}

* respondents indicated 3 greatest risks in their companies

Source: Prepared on the basis of own research.

When asked about whether they felt that unstable economic conditions is increasing, the surveyed in overwhelming number responded affirmatively $(80 \%$ of responses). Only $7 \%$ of respondents specified that the uncertainty of economic conditions decreases, and 13\% said that the uncertainty of economic conditions is not changing. 
Table 3 Does the uncertainty of economic conditions increases?

\begin{tabular}{|c|c|}
\hline Specification & Response rate \\
\hline Increases & $80 \%$ \\
\hline Decreases & $7 \%$ \\
\hline No changes & $13 \%$ \\
\hline
\end{tabular}

Source: Prepared on the basis of own research.

The increase in instability of the environment in which enterprises operate was unequally assessed by the entrepreneurs conducting business in small and large towns. The smallest percentage of responses confirming the increase in volatility of economic conditions (67\%) was obtained from respondents representing enterprises located in cities with populations above 100,000 inhabitants. In smaller towns the proportion of indications for answers ,instability of economic conditions increases” amounted to 80 percent or more.

\section{The effects of economic instability for the SME sector in the light of the research}

Entrepreneurs participating in the study determined that economic instability mainly affects investment decisions and financial situation of the enterprises. As many as $62 \%$ of entrepreneurs indicated that the result of the uncertainty of economic conditions is reduced propensity to invest. Liquidity risk and the deterioration of the financial situation of the company are the effects of instability in the opinion of more than half of the respondents. The result of economic instability, pointed out by the respondents, is the uncertainty in doing business, reduction of employment and no prospects for development, which in turn can lead to refraining from conducting business activity. What is worth emphasizing is the fact that among the consequences caused by volatility of environment the entrepreneurs participating in a pilot study saw the positives: increased flexibility and increased entrepreneurship.

Table 4 What are the effects of economic instability for the company? *

\begin{tabular}{|c|c|}
\hline Specification & The response rate \\
\hline Reduced propensity to invest & $62 \%$ \\
\hline No prospects for business growth & $29 \%$ \\
\hline Uncertainty in doing business & $52 \%$ \\
\hline Deterioration of the financial situation of the company & $50 \%$ \\
\hline Liquidity risk & $53 \%$ \\
\hline Escape to the shadow economy & $19 \%$ \\
\hline Decrease in employment of the company & $41 \%$ \\
\hline Increased entrepreneurship & $19 \%$ \\
\hline
\end{tabular}




\begin{tabular}{|c|c|}
\hline Increasing flexibility & $34 \%$ \\
\hline Aiming at the discontinuation of business & $19 \%$ \\
\hline
\end{tabular}

* Respondents could indicate all present consequences

Source: Prepared on the basis of own research.

Important from the point of view of the study was to investigate ways of responding of entrepreneurs to changes in the socio-economic environment. Participants of the study were asked whether the instability of the environment in which they operate forces changing of the business model. Majority of them responded affirmatively (59\% of responses). Only 12\% of respondents do not see the need to change their business model.

Table 5 Does the instability of the environment in which enterprises operate forces a change in the business model?

\begin{tabular}{|c|c|}
\hline Specification & The response rate \\
\hline Yes & $59 \%$ \\
\hline No & $12 \%$ \\
\hline Difficult to say & $29 \%$ \\
\hline
\end{tabular}

Source: Prepared on the basis of own research.

The answers obtained can be concluded that the most frequently implemented strategy of action in the conditions of instability of the environment is reduction of the operating costs of the company ( $83 \%$ of responses). More than a half of the respondents indicated that when seeking ways to survive in a turbulent environment they implement innovative solutions that enables the company to be competitive in the market and seek to gain competitive advantage through a better product quality. Subsequently, respondents indicated that their response to the unpredictability of market conditions is to analyze the legal, macroeconomic and financial situation and diversify their business activity. Actions indicated by the respondents taken in the conditions of instable environment should be assessed as adequate to the situation of uncertainty.

\section{Summary}

Dynamics of changes faced by contemporary enterprises is much greater than in earlier periods. This requires the management of the companies to undertake adaptation measures, which will allow the companies to survive and achieve an advantage over competitors, as well as predict possible events and make decisions that will protect the company against the effects of economic instability. Changes in the environment may become an inspiration to create innovative solutions and implement new business models, as well as may be an incentive to the restructuring 
of the company, but they can also lead to the collapse of the company, if the managers do not take corrective actions on time.

The conducted pilot study allowed the author to specify the types of risks faced by entrepreneurs and the effects of economic instability for the companies. Vast majority of entrepreneurs participating in thea study claimed that the companies from the SME sector feel the increasing instability of the external condition of conducting business activity. Respondents indicated that conducting business is mostly hindered by the risk associated with the volatility of the market demand and instability of financial conditions associated with the acquisition of external funds (loans and funds from the EU). Despite the measures taken by the government to facilitate the activities of entrepreneurs, the respondents pointed out that many of the problems in running of the company are caused by the changing, unclear economic law and high costs of hiring employees.

Unpredictable, profound changes in the environment of contemporary enterprises cause considerable risk in doing business, for which management of companies is not always prepared. Due to the instability of the external situation, necessary for the survival and the market success become the internal changes in companies. Participants of the study asked whether the currently observed instability of the environment in which enterprises operate forces changes in the organization of production (change of the business model) in the majority responded affirmatively. This indicates an understanding of the need for a rapid adjustment of the business model of enterprises to an unstable environment. The ability of SME sector enterprises to react flexibly to new socio-economic conditions emerging in the environment can provide these entities with a competitive advantage over large enterprises.

\section{Bibliography}

Brzóska J. (2009), Model biznesowy - wspótczesna forma modelu organizacyjnego zarzqdzania przedsiebiorstwem, Organizacja i Zarządzanie Kwartalnik Naukowy Nr 2(6), Wydawnictwo Politechniki Śląskiej, Gliwice.

Casadeus-Masanell R., Tarzijan J. (2012), Gdy jeden model biznesowy nie wystarcza, Harvard Business Review, Nr 7-8 (113/114).

Czarna lista barier dla rozwoju przedsiębiorczości 2013, (2013), Lewiatan.

Davenport T.H., Leibold M., Voelpel S. (2006), Strategic management in the innovation economy. Strategy approaches and tools for dynamic innovation capabilities, Wiley, New York.

Duczkowska-Małysz K., Duczkowska-Piasecka M. (2012), Strategiczne zmiany modelu biznesu $w$ warunkach niestabilnego otoczenia $\mathrm{w}$ : Przedsiębiorstwo a narastajaca niestabilność otoczenia, $\mathrm{R}$. Sobiecki, J.W. Pietrewicz (red.) Oficyna Wydawnicza SGH, Warszawa.

Foster R., Kaplan S. (2003), Twórcza destrukecja, Galaktyka, Lódź.

Kotler P., Caslione J.U. (2009), Chaos - zarzqdzanie i marketing w erze turbulencji, MT Biznes, Warszawa. 
Koźmiński A.K. (2004), Zarzqdz̧anie w warunkach niepewności, PWN, Warszawa.

Pietrewicz J.W. (2012), Systemowe uwarunkowania gospodarczej niestabilności i niepewności w: Przedsiebiorstwo a narastajaca niestabilność otoczenia, R. Sobiecki, J.W. Pietrewicz (red.), Oficyna Wydawnicza SGH, Warszawa.

Prz̨edsiebiorczosí w Polsce, (2013), Ministerstwo Gospodarki, Warszawa.

Raport Global Entrepreneurship Monitor - Polska 2012, (2013), PARP, Warszawa.

Schumpeter J.A. (1992), Teoria rozwoju gospodarczego, PWN, Warszawa.

Szymański W. (2012), Niestabilność gospodarcza a szanse prz̨edsiębiorstw, w: Przedsiębiorstwo a narastajaca niestabilność otoczenia, R. Sobiecki, J.W. Pietrewicz (red.), Oficyna Wydawnicza SGH, Warszawa. 